\title{
OPTIMISATION OF ALKALI EXTRACTION OF PALM KERNEL CAKE PROTEIN
}

\author{
FATAH YAH ABD MANAF* and NOOR LIDA HABI MAT DIAN*
}

\begin{abstract}
Palm kernel cake (PKC) is commonly used in animal feed, particularly as ruminant feed to supply protein and energy. There is little information on the properties of protein concentrate produced from the PKC which constitute 14\%-17\% of the meal. Protein concentrates can be produced from PKC using alkali extraction, where PKC is extracted with an alkali solution and followed by precipitation at the isoelectric point. Thus, this study examined the effects of extraction using several extractants at different conditions; meal ratio of 0.5:50-3.0:50 g ml-1, concentration of 0.1-1.0 M, pH 1-12, temperature of $30^{\circ} \mathrm{C}-80^{\circ} \mathrm{C}$ and time duration of 30-180 min. Sodium hydroxide $(\mathrm{NaOH})$ was found to be the most suitable alkali for protein extraction. Optimum conditions for protein extraction were obtained at $1.0 \mathrm{M} \mathrm{NaOH}$ concentration, $50^{\circ} \mathrm{C}$ temperature, meal to solvent ratio of 2:50 $\left(\mathrm{g} \mathrm{ml}^{-1}\right), \mathrm{pH} 12$ and $120 \mathrm{~min}$. The extracted protein was isolated by isoelectric precipitation at pH 3.5 using $1.0 \mathrm{M}$ hydrochloric acid (HCI). The percentage of protein recovery was 80\%-86\%. Protein content in the recovery ranged from 45\%-50\%. Analysis by high performance liquid chromatography (HPLC) showed that arginine, glutamic acid, phenylalanine and leucine were the most abundant amino acids in the concentrates.
\end{abstract}

\section{Keywords: alkali extraction, isoelectric precipitation, palm kernel cake, protein concentrate.}

Received: 24 June 2020; Accepted: 29 January 2021; Published online: 1 April 2021.

\section{INTRODUCTION}

Malaysia produced about 4.86 million tonnes of palm kernels in 2018 of which 2.59 million tonnes of meal, also known as palm kernel cake (PKC) was produced as a by-product (Kushairi et al., 2019). Of this, 2.29 million tonnes of PKC were exported and nearly most of them were sent to European countries mostly The Netherland and Germany for use as ingredient in animal feed. Thus, PKC is one of the most important by-products in the palm oil industry that generates substantial export earnings for Malaysia at approximately RM1016 million.

PKC is produced from kernel by extracting the oil through screw press or by solvent extraction. Extraction with solvent leaves lesser residual oil in the meal than that of the expeller extraction. PKC

\footnotetext{
* Malaysian Palm Oil Board,

6 Persiaran Institusi, Bandar Baru Bangi,

43000 Kajang, Selangor, Malaysia.

E-mail: fatahyah@mpob.gov.my
}

is light to dark brown colour, where the expellerextracted PKC is darker than those extracted by solvent. Most of the PKC are from mechanical extraction using screw press because solvent extraction is expensive. PKC has high oil content, $2 \%-9 \%$ on average and protein content in the range of $14 \%-17 \%$ (Table 1). Besides oil and protein, PKC also has high fibre content (Alimon, 2004) and high phosphorous to calcium ratio (Tang, 2001). It is suitable for use in animal feed, particularly as ruminant feed to supply protein and energy. Table 2 shows the amino acid profile of PKC. Glutamic acid and arginine are the most abundant amino acids in PKC.

The extraction of protein from oilseeds such as soyabean, canola and peanut has been the subject of research over the last five decades. Soya protein, in particular, has gained many applications in food, fibre and paper products industries. The suitability of PKC protein for both food and nonfood applications is not yet known. A large number of researchers are concerned with the use of meal 
TABLE 1. PROXIMATE ANALYSIS OF PALM KERNEL CAKE

\begin{tabular}{lcc}
\hline Extractant (\%) & $\begin{array}{c}\text { Mechanical } \\
\text { extraction }\end{array}$ & $\begin{array}{c}\text { Solvent } \\
\text { extraction }\end{array}$ \\
\hline Protein & 14.8 & 17.0 \\
Shell & 3.9 & 4.2 \\
Moisture & 7.0 & 9.4 \\
Oil content & 8.9 & 2.0 \\
\hline
\end{tabular}

Source: Siew (1989).

as animal feed sold at a low price to Europe. Over 2 million tonnes of PKC are produced annually in Malaysia. Assuming that the PKC has protein content of $17 \%$ and $55 \%-60 \%$ of these proteins can be extracted, this will ultimately produce almost $200000 \mathrm{t}$ of protein from the PKC and generate more value-added palm oil products.

There are several methods that can be used to extract protein, such as isoelectric precipitation, ultrafiltration and membrane technology. Ultrafiltration can be used to recover low molecular weight protein. The ultrafiltration and membrane technology have been successfully used to produce protein isolates and concentrates from jojoba meal (Abbott et al., 1991; Nabetani et al., 1995), Crambe abyssinica (Massoura et al., 1998), Rosa rubiginosa seeds (Moure et al., 2001), canola (Ghodsvali et al., 2005), oilseed flour (Lawhon et al., 2006) and soyabean (De Moura et al., 2010).

Furthermore, separation of protein from alkali solution by isoelectric precipitation is very common. To date, this method has been successfully applied to flaxseed, soyabean, canola, Lupinus campestris, peanuts, sunflowers and many others (Franzen and Kinsella 1976; Abbasy et al., 1981; Taha et al., 1981; Tzeng et al., 1990; Ghodsvali et al., 2005; RodríguezAmbriz et al., 2005; Alu'datt et al., 2013; Gherzova et al., 2015). In addition, this method is comparatively cheaper and straightforward, and has also been successfully used for extraction of protein from rapeseed (El-Nockrashy et al., 1977) and almond (SzeTsao and Sathe, 2000). The isoelectric precipitation method consists of protein extraction from the cake using alkali solution, and followed by precipitation at isoelectric point. Isoelectric precipitation occurs when there is a change in $\mathrm{pH}$ in the solution.

The extraction of protein by alkali extraction is affected by many factors, such as meal to solvent ratio, protein solubility, temperature and time. It is then followed by precipitation of significant protein fractions at isoelectric point, which ranges from $\mathrm{pH}$ 3.0 to 5.0. Donna et al. (1997) developed the alkaline extraction technique to obtain the optimum protein extraction from canola meal. The extraction was carried out using sodium hydroxide $(\mathrm{NaOH})(0.4 \%)$ and the sample to solvent ratio was 1 to 20. The extraction was carried out at room temperature for
TABLE 2. AMINO ACID CONTENTS OF PALM KERNEL CAKE (g/16 g N)

\begin{tabular}{lc}
\hline Amino acid & $\%$ \\
\hline Alanine & 3.83 \\
Arginine & 11.56 \\
Aspartic acid & 3.63 \\
Cystine & 1.13 \\
Glycine & 4.17 \\
Glutamic acid & 16.80 \\
Histidine & 1.91 \\
Isoleucine & 3.22 \\
Leucine & 6.07 \\
Lysine & 2.68 \\
Methionine & 1.75 \\
Phenyalanine & 3.96 \\
Proline & 3.31 \\
Serine & 4.11 \\
Threonine & 2.75 \\
Tryptophan & 1.06 \\
Tyrosine & 2.60 \\
Valine & 5.05 \\
\hline
\end{tabular}

Source: Alimon (2004).

$60 \mathrm{~min}$. The protein obtained using the precipitation method at isoelectronic point $(\mathrm{pH} \mathrm{4})$ was relatively high at $87.5 \%$. A study by Liadakis et al. (1998) found that the yield of protein extract from tomato increased at a temperature between $30^{\circ} \mathrm{C}-50^{\circ} \mathrm{C}$. Kwon et al. (1996) found that temperature of up to $60^{\circ} \mathrm{C}$ gave higher protein yield from coconut meal but the protein produced was denatured.

All oilseed meals have different isoelectric points. Generally, protein concentrates or isolates are precipitated at isoelectric point between $\mathrm{pH}$ 3.05.0. The $\mathrm{pH}$ adjustment of the extract supernatant is normally carried out using dilute acidic solutions. Previous studies have reported the adjustment of $\mathrm{pH}$ to 3.5 using acetic acid (Klockeman et al., 1997) or hydrochloric acid (Tzeng et al., 1990). The isoelectric points for soyabeans (Franzen et al., 1976), canola (Klockeman et al., 1997) and sunflower (Taha et al., 1981) meals are at $\mathrm{pH} \mathrm{4,} 3.5$ and 3.4, respectively. A similar study by Xu and Diosady (2003) found that the highest protein yield (50\%) for rapeseed meals was obtained between $\mathrm{pH} 4.5$ to 5.0. The isoelectric point for PKC is not yet known but based on the reference to oilseeds such as soyabean and canola, it is deemed to be at $\mathrm{pH} 3.5$. Thus, this article highlights on the optimisation of various parameters, such as $\mathrm{pH}$, temperature, time, extractant and meal to solvent ratio on alkali extraction of PKC to produce high protein concentrate. 


\section{MATERIALS AND METHODS}

\section{Materials}

Mechanical-extracted PKC was provided by a mill in Klang, Selangor, Malaysia. The cake was ground to pass through 80 mess screen. AccQ Tag Chemistry packages for amino acid analysis consisting of 6-aminoquinolyl-N-hydroxysuccinimidyyl carbamate (AccQ) fluor reagent, AccQ Tag eluent and amino acid standard were obtained from Waters, USA. The internal standard, $\alpha$ amino butyric acid (AABA), was purchased from Sigma-Aldrich, USA. Hydrochloric acid and acetonitrile of high performance liquid chromatography (HPLC) grade were purchased from Merck, Germany. High purity water was supplied by Milli-Q purification system.

\section{Proximate Analysis}

Ash, moisture and oil contents were determined according to Association of Official Analytical Chemists (AOAC) method (1990).

\section{Total Protein Content}

Crude protein in PKC was determined by conventional acid hydrolysis and Kjeldahl digestion using selenium catalyst according to the method described in AOAC (1995). Ammonia was distilled and collected in boric acid solution, which was then titrated using $0.1 \mathrm{~N}$ hydrochloric acid (HCI). Digestion and distillation were carried out using Kjeltec apparatus (Model 2200 Auto Distillation, Foss Tecator, Denmark).

\section{Determination of Optimisation of Alkali Extraction}

Protein concentrates were prepared from PKC by alkaline extraction using the method described by Oomah et al. (1994) as shown in Figure 1. The extraction was performed with several extractants at different conditions; $\mathrm{NaOH}$ concentration of 0.1-1.0 M; meal to solvent ratio of 0.5:50, 1:50, 1.5:50, 2.0:50, 3.0:50 v/w; pH 1-12; temperature of $30^{\circ} \mathrm{C}-70^{\circ} \mathrm{C}$; and duration of $30-180 \mathrm{~min}$. The slurry was then centrifuged at $10000 \mathrm{~g}$ (Sorval RC-5C Plus, USA) for $10 \mathrm{~min}$ at $10^{\circ} \mathrm{C}$ and followed by filtration through Whatman No. 41 filter paper. The protein extracted was then precipitated by adjusting the $\mathrm{pH}$ to the isoelectric point and centrifuged at $5000 \mathrm{~g}$ for $10 \mathrm{~min}$. The precipitated curd was then washed with distilled water and dried.

\section{Protein Solubility}

Protein solubility was measured as a function of $\mathrm{pH}$ (1-12.0). Twelve sets of $1 \mathrm{~g}$ sample each were dispersed in $50 \mathrm{ml}$ of $1.0 \mathrm{M} \mathrm{NaOH}$ and each solution was adjusted to $\mathrm{pH}$ between 1 to 12 by adding either $\mathrm{NaOH}$ or $\mathrm{HCl}$. The dispersion was agitated for $2 \mathrm{hr}$ at $50^{\circ} \mathrm{C}$ and then centrifuged at $10000 \mathrm{~g}$ for $15 \mathrm{~min}$, followed by filtration through Whatman No.1 filter paper. Nitrogen $(\mathrm{N})$ content in the supernatant was determined by Kjeldhal method. The percentage of soluble protein was calculated as follows:

$\begin{gathered}\text { Protein } \\ \text { solubility } \\ (\%)\end{gathered}=\frac{\begin{array}{c}\text { amount of } \mathrm{N} \text { in the } \\ \text { supernatant }\end{array}}{\text { amount of } \mathrm{N} \text { in the PKC }} \times 100$

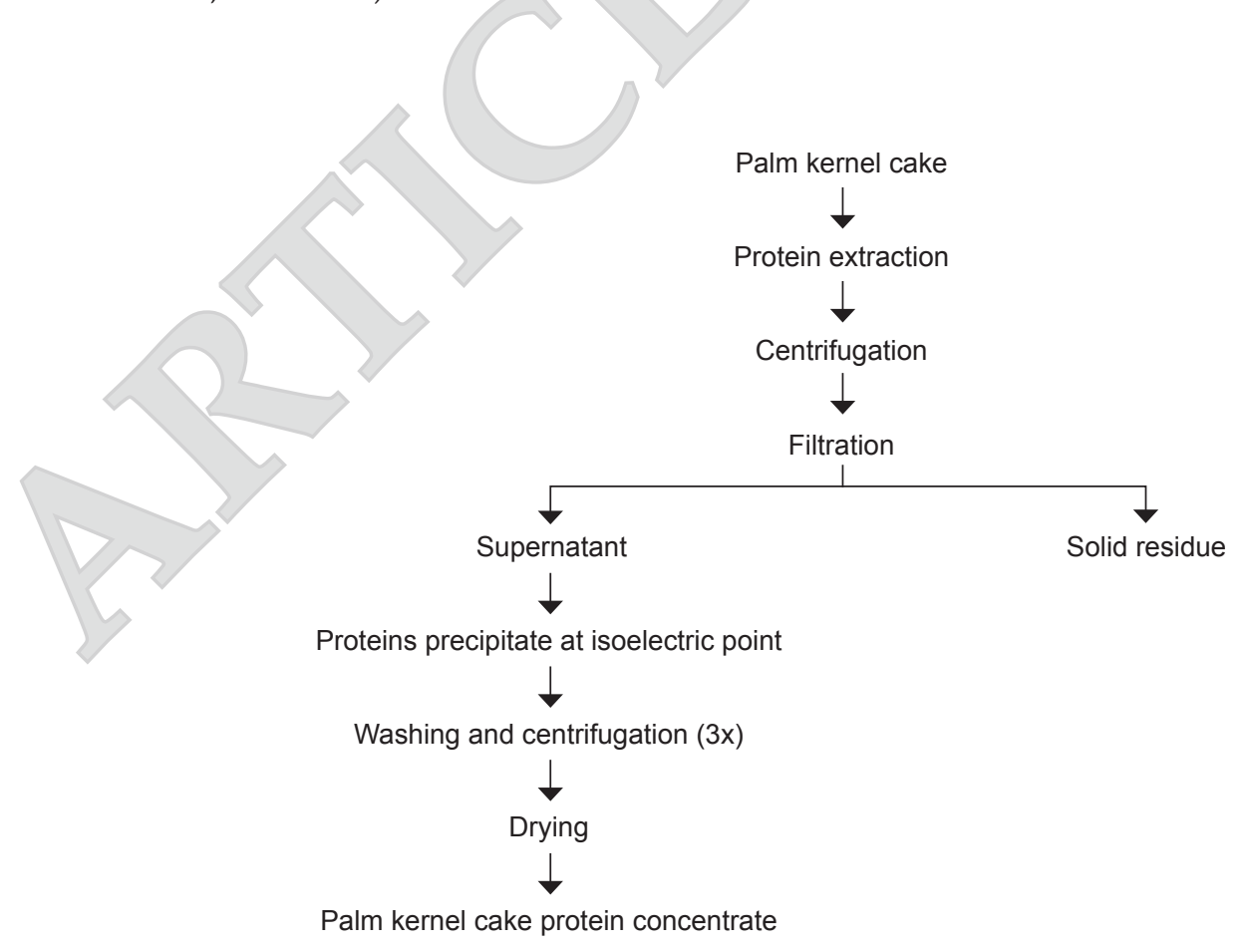

Figure 1. Process flow of alkali precipitation for palm kernel cake protein extraction. 


\section{Determination of Isoelectric Point}

Four sets of PKC extracted with $\mathrm{NaOH}(100$ $\mathrm{ml}$ each) were placed in $250 \mathrm{ml}$ flasks. The extracts were tested at different $\mathrm{pH}$ of 3.0, 3.5, 4.0 and 4.5. The protein curd formed was then separated by centrifugation for $15 \mathrm{~min}$ at $5000 \mathrm{~g}$. The percentage of protein yield was plotted against $\mathrm{pH}$ to determine the isoelectric point. Isoelectric point was indicated by maximum PKC protein yield.

\section{Amino Acid Determination}

A reverse-phase HPLC method using AccQ Tag RP-18 column (3.9x150 mm) was used for the determination of amino acids in PKC and its protein concentrate. The method was conducted based on Waters AccQ Tag method that is capable of analysing 21 amino acids in $40 \mathrm{~min}$ (Cohen and Michaud, 1993). The detection was carried out by Waters 2475 Multi-Fluorescence Detector with excitation at 250 $\mathrm{nm}$ and emission at $395 \mathrm{~nm}$ (Waters Breeze HPLC System, USA).

\section{RESULTS AND DISCUSSION}

\section{Proximate Analysis}

Analysis showed that the mechanical-extracted PKC contained $14.35 \%$ protein, $13.67 \%$ oil, $13.26 \%$ shell, $4.28 \%$ ash and $8.75 \%$ moisture. The amount of protein obtained in this study was almost similar to that reported by Alimon (2004) and Nuzul Amri (2013), while other components varied depending on the sources and efficiency of the oil extraction operation.

\section{Protein Solubility}

Figure 2 shows the solubility of PKC protein in the $\mathrm{pH}$ range of 1 to 12 . Protein solubility was the highest $(49.45 \%)$ at $\mathrm{pH} 12$. At $\mathrm{pH} 1$, solubility of PKC protein was $10.54 \%$, while minimum solubility occurred at pH 2 to $\mathrm{pH} 9$ (less than $3 \%$ ). The results suggested that there was some portion of the protein not affected by $\mathrm{NaOH}$ solution. This finding is in agreement with that of Osman (2002) who reported on protein entrapped in a hard cell structure in the PKC as the protein of PKC was fully protected by tough cell walls. With an increase in $\mathrm{pH}$, the trapped protein would be freed and unattached, thus, increasing protein concentrate yield.

\section{Isoelectric Point}

Figure 3 shows the isoelectric point for PKC. The samples were tested at different $\mathrm{pH}$ of 3.0, 3.5, 4.0 and 4.5 . The highest protein yield $(81 \%)$ was obtained at $\mathrm{pH}$ 3.5. The results showed that the PKC has its isoelectric point at $\mathrm{pH}$ 3.5. Oilseed meals have isoelectric points at $\mathrm{pH} 4$ for soyabean (Franzen et al., 1976) and pH 4.5 for canola (Klockeman et al., 1997). The isoelectric point ascertains the level of minimum solubility of protein owing to proteinprotein interactions being favoured over proteinwater interactions (Luft et al., 2011). Solubility refers to the amount of protein in a sample that dissolves into solution (Zayas, 1997). This means that protein in $\mathrm{PKC}$ is soluble in solution with $\mathrm{pH}$ of 3.5.

\section{Effect of Different Extractants on PKC Protein Extraction}

$\mathrm{NaOH}$ is the most efficient solvent for the extraction of protein from PKC with the highest $\mathrm{N}$ extractability (83\%). This is also true for other oilseed meals. Wolf (1970) and Donna (1997) found that $\mathrm{NaOH}$ extracted the highest yield of protein from soyabean and canola meal. Terry et al. (1992) found that $76.8 \%$ protein could be extracted from Nigeria seed using $0.1 \mathrm{M} \mathrm{NaOH}$. Alkali solution is effective in solubilising rice bran proteins because $\mathrm{NaOH}$ can break hydrogen, amide, and disulphide

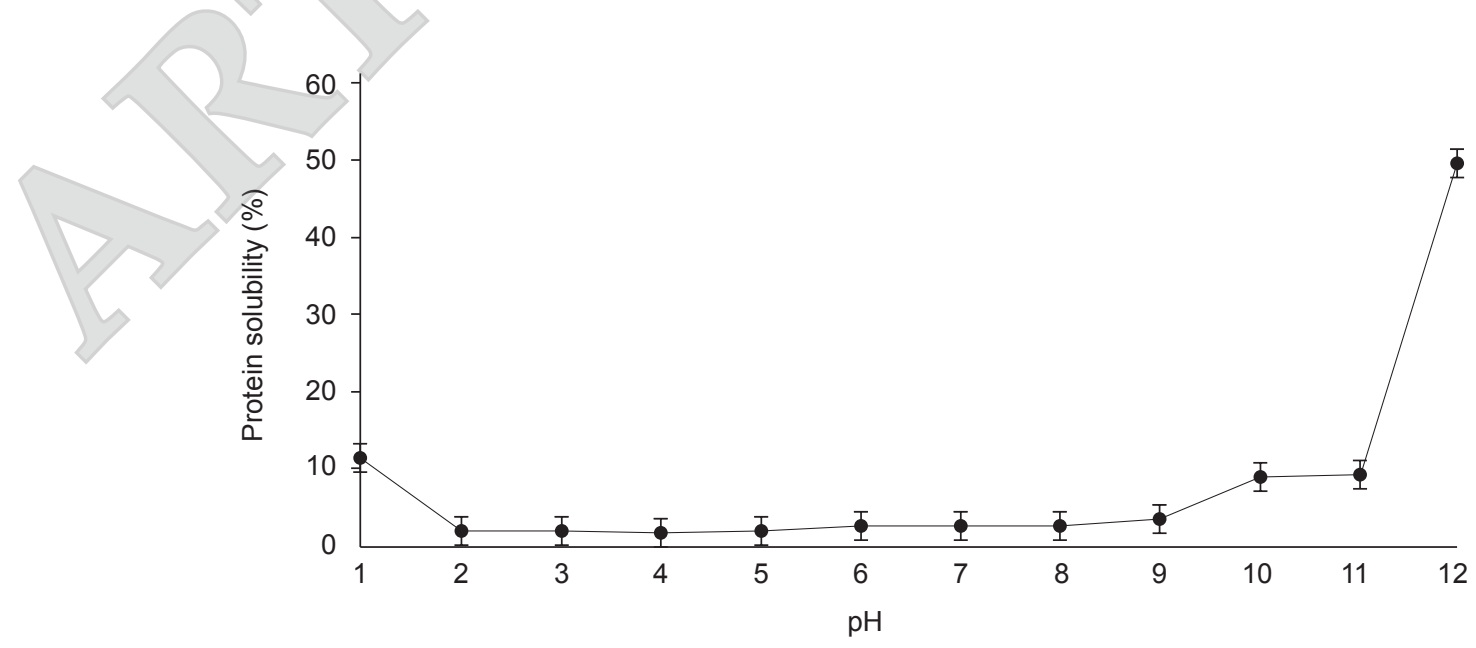

Figure 2. The solubility of palm kernel cake protein as a function of $p H$. 


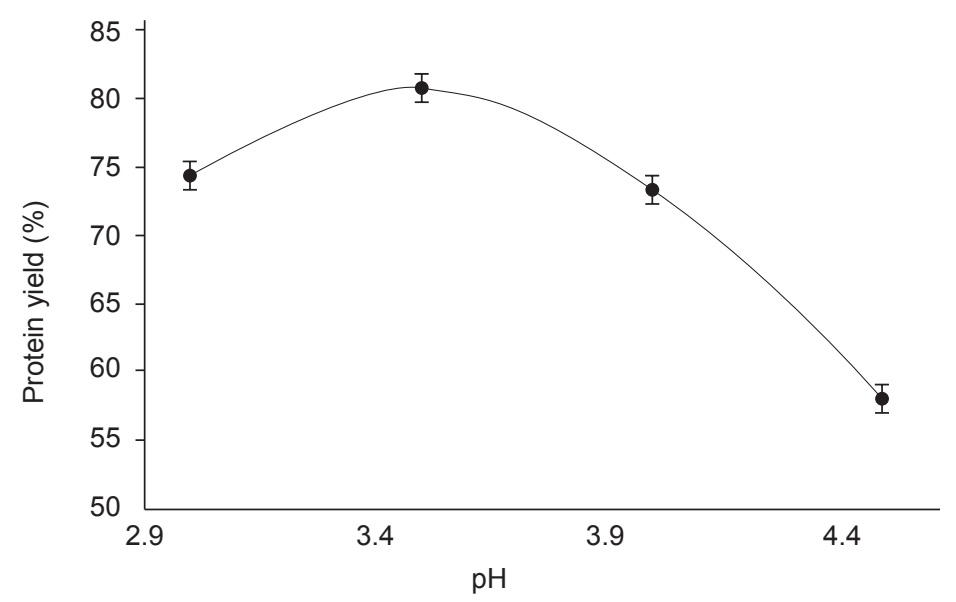

Figure 3. Protein yield of palm kernel cake at different $p H$.

bonds in proteins (Hamada, 1997). Results showed that natrium chloride $(\mathrm{NaCl})$ solution was less effective for PKC protein extraction. According to Cui et al. (2017), presence of hydrophobic groups and disulphide bonds between protein molecules hinders the solubility of protein in water. Thus, this prompts for the use of aqueous solution such as salt, acid and alkali solution, which is beneficial to extract protein due to its large solubility and protein stability. This explains the efficiency of $\mathrm{NaOH}$ in extracting the highest protein from PKC among other extractants. Table 3 shows the effect of different extractants on the extraction of protein from PKC.

\section{TABLE 3. EFFECT OF DIFFERENT EXTRACTANTS ON PALM KERNEL CAKE PROTEIN EXTRACTION}

\begin{tabular}{lc}
\hline Extractant & Protein extracted $(\%)$ \\
\hline $1.0 \mathrm{M}$ potassium hydroxide $(\mathrm{KOH})$ & $71.35 \pm 1.36$ \\
$1.0 \mathrm{M}$ sodium hydroxide $(\mathrm{NaOH})$ & $83.66 \pm 1.80$ \\
$1.0 \mathrm{M}$ natrium chloride $(\mathrm{NaCl})$ & $50.88 \pm 0.21$ \\
Water $\left(\mathrm{H}_{2} \mathrm{O}\right)$ & $1.46 \pm 0.15$ \\
\hline
\end{tabular}

Note: Temperature $-50^{\circ} \mathrm{C}$; extraction time - $2 \mathrm{hr}$; meal to solvent ratio $-1: 50(\mathrm{w} / \mathrm{v})$.

\section{Effect of Different $\mathrm{NaOH}$ Concentrations on PKC Protein Extraction}

Increasing the concentration of $\mathrm{NaOH}$ resulted in high protein yield (Table 4). The protein yield was low (1.20\%-6.36\%) for 0.01-0.5 M NaOH. Increasing the molarity of $\mathrm{NaOH}$ to $1.0 \mathrm{M}$ increased the protein yield to $41.16 \%$. Donna et al. (1997) used $0.04 \mathrm{M}$ $\mathrm{NaOH}$ to obtain optimum protein extraction of $90 \%$ from canola meal. While protein extracted using 0.5 $\mathrm{M} \mathrm{NaOH}$ resulted in less than $10 \%$ yield. Results showed that protein extraction from PKC needed high $\mathrm{NaOH}$ concentration. However, high alkaline concentration facilitates the breakdown of hydrogen bonds and dissociates hydrogen (Cui et al., 2017).
TABLE 4. EFFECT OF SODIUM HYDROXIDE (NaOH) CONCENTRATIONS ON PALM KERNEL CAKE PROTEIN EXTRACTION

\begin{tabular}{cc}
\hline Molarity of $\mathrm{NaOH}(\mathrm{M})$ & Protein extracted $(\%)$ \\
\hline 0.01 & $1.20 \pm 0.28$ \\
0.05 & $1.90 \pm 0.21$ \\
0.10 & $2.94 \pm 0.45$ \\
0.25 & $3.13 \pm 0.33$ \\
0.50 & $6.36 \pm 1.05$ \\
1.00 & $43.71 \pm 1.22$ \\
\hline
\end{tabular}

Note: Temperature $-50^{\circ} \mathrm{C}$; extraction time - $1 \mathrm{hr}$; extraction $\mathrm{NaOH}$; meal to solvent ratio - 1:50 (w/v).

\section{Effect of Meal to Solvent Ratio on PKC Protein Extraction}

Table 5 shows the protein yield extracted at various ratios of meal to solvent. Other process parameters were fixed at $50^{\circ} \mathrm{C}, 1 \mathrm{hr}$ extraction and $50 \mathrm{ml}$ of $\mathrm{NaOH}(1.0 \mathrm{M})$. Results showed that low meal to solvent ratio resulted in high protein yield. This study is in agreement with Taha (1987) who successfully extracted $91.4 \%$ protein from sesame seed using $0.4 \mathrm{M} \mathrm{NaOH}$ to sample ratio of $1: 25$. Increasing the meal to solvent ratio resulted in decrease in $\mathrm{N}$ extractability at any $\mathrm{NaOH}$ concentration. Meal to solvent ratio of 0.5:50 and 1.0:50 (w/v) did not have significant effect on protein yield. Thus, meal to solvent ratio of 1:50 $(\mathrm{w} / \mathrm{v})$ was found to be the satisfactory condition for PKC extraction.

\section{Effect of Time on PKC Protein Extraction}

Extraction time is one of the factors that also influences protein yield. However, time factor has less significance on the extraction yield. Results showed that the longer the extractability duration, 
TABLE 5. EFFECT OF MEAL TO SOLVENT RATIO ON PALM KERNEL CAKE PROTEIN EXTRACTION

\begin{tabular}{cc}
\hline Sample $(\mathrm{g})$ & Protein extracted $(\%)$ \\
\hline 0.5 & $87.53 \pm 2.43^{\mathrm{a}}$ \\
1.0 & $87.87 \pm 2.97^{\mathrm{a}}$ \\
1.5 & $85.16 \pm 1.64^{\mathrm{b}}$ \\
2.0 & $74.92 \pm 3.23^{\mathrm{c}}$ \\
2.5 & $69.84 \pm 1.86^{\mathrm{d}}$ \\
3.0 & $64.91 \pm 4.19^{\mathrm{e}}$ \\
\hline
\end{tabular}

Note: Temperature $-50^{\circ} \mathrm{C}$; extraction time $-2 \mathrm{hr}$; extractant $-1.0 \mathrm{M}$ sodium hydroxide $(\mathrm{NaOH})$; volume of $\mathrm{NaOH}-50 \mathrm{ml}$. Means with the same letters are not significant different $(\mathrm{p}>0.05)$.

the higher the protein yield until it reached a plateau at $120 \mathrm{~min}$ (Table 6). Cui et al. (2017) also revealed that long extraction time improved protein extracted from tea. Thus, the optimum extraction time that can produce the highest protein yield from PKC was 120 min.

\section{Effect of Temperature on PKC Protein Extraction}

Study on the effect of temperature on protein yield was carried out at $30^{\circ} \mathrm{C}, 40^{\circ} \mathrm{C}, 50^{\circ} \mathrm{C}, 60^{\circ} \mathrm{C}$ and $70^{\circ} \mathrm{C}$, and the process parameters were fixed at $2 \mathrm{hr}$ extraction time and meal to $\mathrm{NaOH}(1.0 \mathrm{M})$ ratio of 1:50 $(\mathrm{w} / \mathrm{v})$ as shown in Table 7. Protein extraction was the lowest $(61.19 \%)$ at $30^{\circ} \mathrm{C}$. Increasing the temperature resulted in protein yield increment. High temperature stress may trigger changes in plant tissue affecting physiological processes (Lurie, 2006). Zhang et al. (2009) emphasised that increasing temperature could induce mass transfer and solubility, reduce viscosity of the solution and thus, increase the extraction rate. However, the extraction should not be performed at high temperatures due to the possibility of protein denaturation. According

TABLE 6. EFFECT OF TIME ON PALM KERNEL CAKE PROTEIN EXTRACTION

\begin{tabular}{|cc}
\hline Time (min) & Protein extracted (\%) \\
\hline 30 & $61.38 \pm 3.20^{\mathrm{c}}$ \\
60 & $76.47 \pm 2.63^{\mathrm{b}}$ \\
90 & $80.72 \pm 3.11^{\mathrm{a}, \mathrm{b}}$ \\
120 & $82.19 \pm 1.57^{\mathrm{a}, \mathrm{b}}$ \\
150 & $82.75 \pm 2.72^{\mathrm{a}}$ \\
180 & $83.15 \pm 5.11^{\mathrm{a}}$ \\
\hline
\end{tabular}

Note: Temperature $-50^{\circ} \mathrm{C}$; meal to solvent ratio - $1: 50(\mathrm{w} / \mathrm{v})$; extractant - $1.0 \mathrm{M}$ sodium hydroxide $(\mathrm{NaOH})$.

Means with the same letters are not significant different ( $\mathrm{p}>0.05)$. to Lee et al. (2003) who examined the impact of temperature on protein yield in soyabean, soya protein meal denatured at $60^{\circ} \mathrm{C}$. Thus, $50^{\circ} \mathrm{C}$ was found to be the satisfactory temperature for PKC protein extraction.

\section{Protein Extraction at Optimum Condition}

After the optimum conditions were established, the protein concentrates extracted from PKC was carried out at $50^{\circ} \mathrm{C}$ and stirred continuously at 200 rpm for $2 \mathrm{hr}$ using meal to $\mathrm{NaOH}(1.0 \mathrm{M})$ ratio of 1:50 $(\mathrm{w} / \mathrm{v})$. The suspension was then centrifuged at $10000 \mathrm{~g}$ for $10 \mathrm{~min}$ at $10^{\circ} \mathrm{C}$, followed by filtration through Whatman No. 41 filter paper. Extracted protein in the supernatant was precipitated by adjusting the $\mathrm{pH}$ to isoelectric point at $\mathrm{pH} 3.5$ with $1.0 \mathrm{M} \mathrm{HCl}$ and then separated by centrifugation at $5000 \mathrm{~g}$ for $10 \mathrm{~min}$. The precipitated curds were then washed with distilled water and dried. The protein recovery was $80 \%$ to $86 \%$. Optimisation of protein extraction will enhance its nutritive values for animal feed application. Protein deficiency may reduce body protein deposition and animal performance, where part of the essential amino acids diverts to nonessential amino acids synthesis due to lack of nonspecific nitrogen for this process (Dean et al., 2006).

\section{Amino Acid Composition}

Amino acid is an important measure of protein quality (Bryden and Li, 2010). Amino acid for feed is crucial in improving the efficiency of utilising protein in animal feed (Toride, 2000). Seventeen amino acids were separated and detected in PKC and its protein concentrate, namely glutamic acid, aspartic acid, alanine, arginine, cysteine, glycine, histidine, isoleucine, leucine, lysine, methionine, phenylalanine, proline, serine, threonine, tyrosine and valine. Tryptophan was destroyed by acid hydrolysis; this is not shown in the chromatogram. There was also loss of cysteine and methionine in very low analytical values.

TABLE 7. EFFECT OF TEMPERATURE ON PALM KERNEL CAKE PROTEIN EXTRACTION

\begin{tabular}{cc}
\hline Temperature $\left({ }^{\circ} \mathrm{C}\right)$ & Protein extracted $(\%)$ \\
\hline 30 & $68.19 \pm 2.09^{\mathrm{c}}$ \\
40 & $75.00 \pm 1.78^{\mathrm{b}}$ \\
50 & $86.45 \pm 2.52^{\mathrm{a}}$ \\
60 & $86.58 \pm 1.41^{\mathrm{a}}$ \\
70 & $85.21 \pm 2.37^{\mathrm{a}}$ \\
\hline
\end{tabular}

Note: Extraction time - $2 \mathrm{hr}$; meal to solvent ratio - 1:50 (w/v); extractant $-1.0 \mathrm{M}$ sodium hydroxide $(\mathrm{NaOH})$.

Means with the same letters are not significant different $(\mathrm{p}>0.05)$. 
The amino acid compositions and HPLC chromatogram of PKC and its protein concentrate are presented in Figures 4, 5 and Table 8, respectively. Acid composition in PKC is similar as reported by Alimon (2004). Glutamic acid was the most abundant amino acid, while lysine was the least amino acid in PKC. PKC protein concentrate was found to be rich in arginine, glutamic acid and phenylalanine.

\section{CONCLUSION}

$\mathrm{NaOH}$ was found to be the most suitable solvent for protein extraction. The optimum condition for protein extraction was $1.0 \mathrm{M} \mathrm{NaOH}, 50^{\circ} \mathrm{C}$, meal to solvent ratio of 1:50 (w/v), pH 12 and 120 min time reaction. The extracted protein was isolated by isoelectric precipitate at $\mathrm{pH} 3.5$ using $1.0 \mathrm{M}$ $\mathrm{HCI}$ acid. The percentage of protein recovery was $80 \%-86 \%$. Total recovered protein content was between $45 \%-50 \%$. Analysis by HPLC showed that arginine, glutamic acid, phenylalanine and leucine were the most amino acids present in PKC protein concentrates.

\section{ACKNOWLEDGEMENT}

The authors would like to thank the DirectorGeneral of MPOB for permission to publish this article.

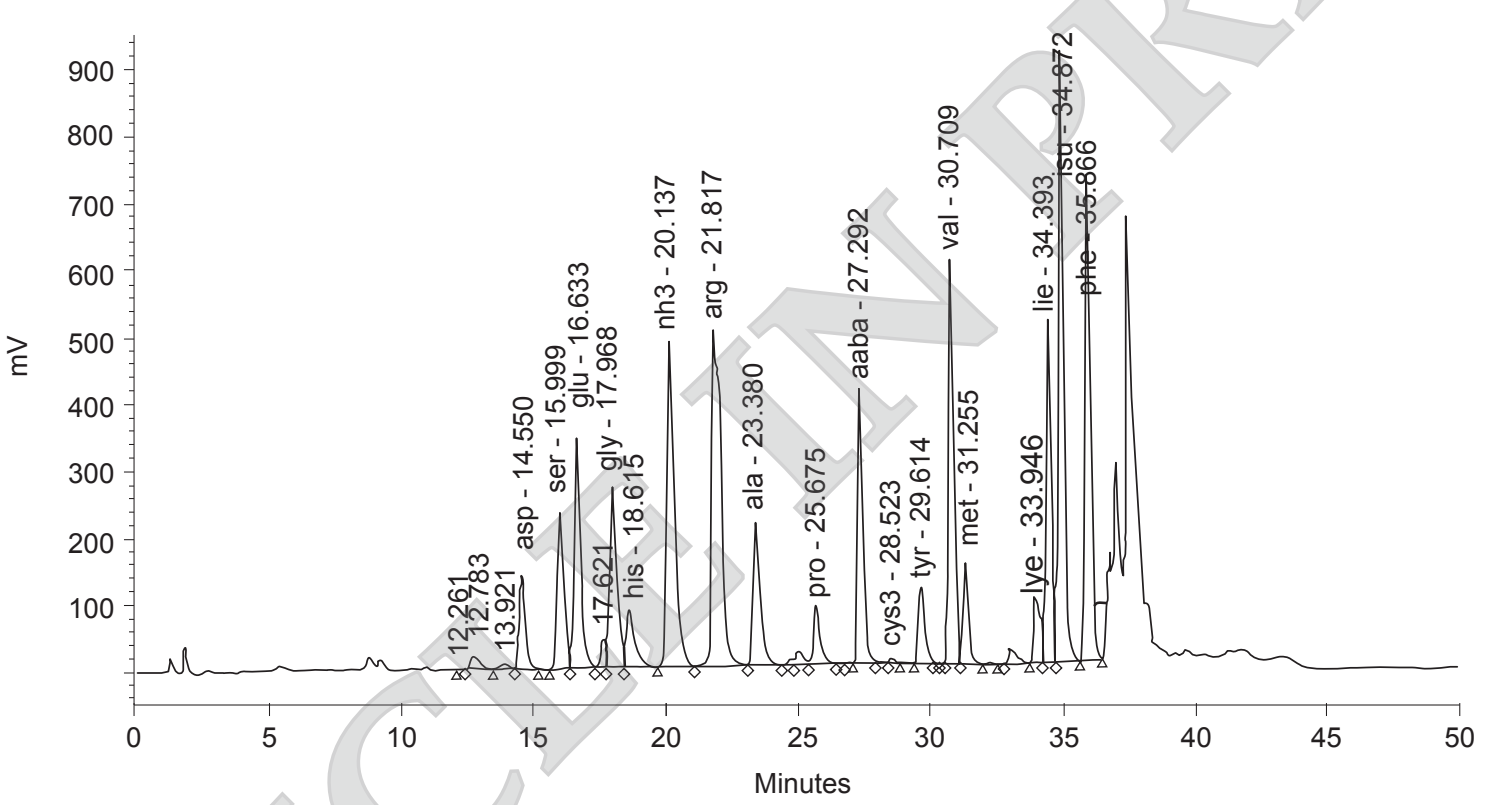

Figure 4. Amino acid chromatogram of palm kernel cake.

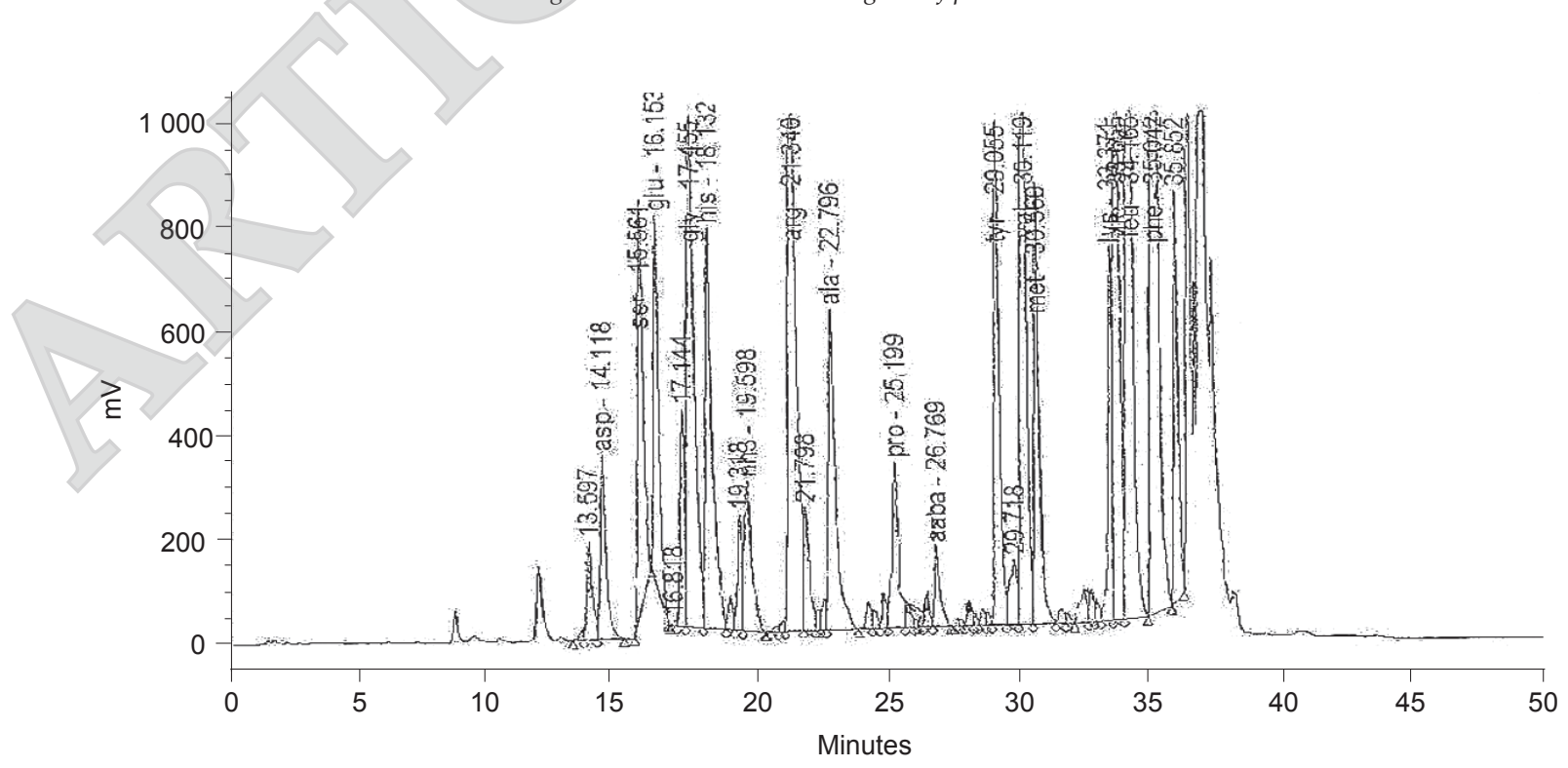

Figure 5. Amino acid chromatogram of palm kernel cake protein concentrates. 
TABLE 8. AMINO ACID COMPOSITIONS IN PALM KERNEL CAKE (PKC) AND ITS PROTEIN CONCENTRATE

\begin{tabular}{|c|c|c|}
\hline Amino acid & PKC (g/16 g N) & $\begin{array}{l}\text { Protein concentrate } \\
\text { (g/100 g protein) }\end{array}$ \\
\hline Alanine & 0.92 & 1.19 \\
\hline Arginine & 2.18 & 4.75 \\
\hline Aspartic acid & 1.55 & 3.71 \\
\hline Cystine & 0.20 & 0.25 \\
\hline Glutamic acid & 3.01 & 6.96 \\
\hline Glycine & 0.83 & 1.14 \\
\hline Histidine & 0.29 & 2.49 \\
\hline Isoleucine & 0.62 & 1.99 \\
\hline Leucine & 1.11 & 3.45 \\
\hline Lysine & 0.59 & 1.46 \\
\hline Methionine & 0.30 & 1.87 \\
\hline Phenylalanine & 0.73 & 6.46 \\
\hline Proline & 0.63 & 1.32 \\
\hline Serine & 0.69 & 0.89 \\
\hline Theorinne & 0.55 & 2.41 \\
\hline Tyrosine & 0.38 & 1.87 \\
\hline Valine & 0.90 & 2.40 \\
\hline Total & 14.35 & 44.61 \\
\hline
\end{tabular}

\section{REFERENCES}

Abbasy, M; Taha, F S and Hamouda, A A (1981). A protein isolate by countercurrent and isoelectric precipitation of peanuts. Grasas-y-Aceite, 32: 171175.

Abbott, T P; Nakamura, L K; Buchholz, G; Wolf, W J; Palmer, D M; Gasdorf, H J; Nelsen, T C and Kleiman, R (1991). Process for making animal feed and protein isolates from jojoba meal. J. Agric. Food Chem., 39; 1488-1493.

Alimon, A R (2004). The nutritive value of palm kernel cake for animal feed. Palm Oil Developments, 40: 12-16.

Alu'datt, M H; Rababah, T; Ereifej, K; Brewer, S and Alli, I (2013). Phenolic-protein interactions in oilseed protein isolates. Food Res. Int. 52(1): 178-184.

AOAC (1995). Official Methods of Analysis. $16^{\text {th }}$ edition. Arlington, VA. Association of Official Analytical Chemists (AOAC).

AOAC (1990). Official Methods of Analysis. 15 ${ }^{\text {th }}$ edition. Washington, USA. Association of Official Analytical Chemists (AOAC).
Bryden, W L and Li, X (2010). Amino acid digestibility and poultry feed formulation: Expression, limitations and application. R. Bras. Zootec., 39: 279-287.

Cohen, S A and Michaud, D P (1993). Synthesis of a fluorescent derivatizing reagent for 6-amino quinolyl-N-hydroxysuccinimidyl carbamate and its application for the analysis of hydrolysate amino acids via high-performance liquid chromatography. Anal. Biochem., 211: 279-887.

Cui, Q; Ni, X; Zeng, L; Zheng, T; Li, J; Sun, K; Chen, $X$ and Li, X (2017). Optimization of protein extraction and decoloration conditions for tea residues. Horticultural Plant J., 3(4): 172-176.

De Moura, J M L N; Campbell, K; de Almeida, N M; Glatz, C E and Johnson, L A (2010). Protein extraction and membrane recovery in enzymeassisted aqueous extraction processing of soybeans. J. Amer. Oil Chem. Soc. DOI 10.1007/s11746-010$1737-0$.

Dean, D W; Bidner, T D and Southern, L L (2006). Glycine supplementation to low protein, amino acid supplemented diets supports optimal performance of broiler chicks. Poultry Science, 85(2): 288-296.

Donna, M K; Romeo, T and Kevin, A S (1997). Isolation and characterization of defatted canola meal protein. J. Agric. Food Chem., 45: 3867-3870.

El-Nockrashy, A S; Mukherjee, K D and Manguld, H K (1977). Rapeseed protein isolate by countercurrent extraction and isoelectric precipitation. J. Agric. Food Chem., 25: 193-197.

Franzen, K L and Kinsella, J E (1976). Functional properties of succinylated and acetylated soy protein. J. Agric. Food Chem., 24: 788-795.

Gerzhova, A; Mondor, M; Benali, $\mathrm{M}$ and Aider, M (2015). A comparative study between the electroactivation technique and conventional extraction method on the extractability, composition and physicochemical properties of canola protein concentrates and isolates. Food Biosci., 11: 56-71.

Ghodsvali, A; Haddad Khodaparast, M H; Vosoughi, M and Diosady, L L (2005). Preparation of canola protein materials using membrane etechnology and evaluation of meals functional properties. Food Res. Int., 38(2): 223-231.

Kwon, K S; Bae, D; Park, K H and Rhee, K C (1996). Aqueous extraction and membrane techniques improve coconut protein concentrate functionality. J. Food. Sc., 61: 753-756. 
Klockeman, D M; Toledo, R and Sims, K A (1997). Isolation and characterization of defatted canola meal protein. J. Agric Food Chem., 45: 3867-3870.

Kushairi, A; Meilina, O-A; Balu, N; Elina, H; Zanal Bidin, M N R; Razmah, G; Vijaya, S; Shamala, S and Ahmad Parveez, G K (2019). Oil palm economic performance in Malaysia and $R \& D$ progress in 2018. J. Oil Palm Res. Vol. 31: 165-194.

Lawhon, J T; Mulsow, D; Cater, C M and Mattil, K F (2006). Production of protein isolates and concentrates from oilseed flour extracts using industrial ultrafiltration and reverse osmosis systems. J. Food Sci., 42(2): 389-394.

Lee, K H; Ryu, H S and Rhee, K C (2003). Protein solubility characteristics of commercial soy protein products. J. Amer. Oil Chem. Soc., 80: 85-90.

Liadakis, G N; Tzia, C; Oreopoulou, V and Thomopoulos, C D (1998). Isolation of tomato seed meal proteins with salt solutions. J. Food Science, 63: 450-453.

Luft, J R; Wolfley, J R and Snell, E H (2011). What's in a drop? Correlating observations and outcomes to guide macromolecular crystallization experiments. Crystal Growth and Design, 11(3): 651-663.

Lurie, S (2006). The effect of high temperature treatment on quality of fruits and vegetables. Acta Horticulturae, 712: 165-174.

Hamada, J S (1997). Characterization of protein fractions of rice bran to devise effective methods of protein solubilization. Cereal Chem., 74: 662-668.

Massoura, E; Vereijken, J M; Kolster, P and Derksen, J T P (1998). Protein from Crambe Abyssinia oilseed. 1. Isolation procedure. J. Amer. Oil Chem. Soc., 75: 324-327.

Moure, A; Sineiro, J and Dominguez, H (2001). Extraction and functionality of membraneconcentrated protein from defatted Rosa rubiginosa seeds. Food Chem., 74(3): 327-339.

Nabetani, H; Abbott, T P and Kleiman, R (1995). Ultrafiltration and Microfiltration Handbook. Ind. Engr. Chem. Res., 34: 1779.

Nuzul Amri, I (2013). Characteristics of Malaysian palm kernel and its products. J. Oil Palm Res. Vol. 25(2): 245-252.

Oomah, B D; Mazza, G and Cui, W (1994). Optimization of protein extraction from flaxseed meal. Food Research International, 27(4): 355-361.
Osman, A (2002). Preliminary study of protein solubility of palm kernel cake in $\mathrm{NaOH}$. Proc. of the National Seminar on Palm Oil Milling, Refining, Technology, Quality and Environment (POMREQ) 2002. MPOB, Bangi.

Rodríguez-Ambriz, S L; Martínez-Ayala, A L; Millán, F and Davila-Ortiz, G (2005). Composition and functional properties of Lupinus campestris protein isolates. Plant Foods for Hum. Nutr., 60(3): 99-107.

Siew, W L (1989). Characteristics and uses of Malaysian palm kernel cake. PORIM Technology No. 14: 2-3.

Sze-Tao, K W C and Sathe, S K (2000). Functional properties and in vitro digestibility of almond (Prunus dulcis L.) protein isolate. Food Chemistry, 69: 153-160.

Taha, F S; Fahmy, M and Sadek, M A (1987). Lowphytate protein concentrate and isolate from sesame seed. J. Agri. Food Chemistry, 35(3): 289292.

Taha, F S; Abbasy, M; El-Nockrashy, A S and Shoeb, Z E (1981). Countercurrent extraction-isoelectric precipitation of sunflower seed protein isolates. J. Sci. Food Agric., 32: 166-174.

Tang, T S (2001). Quality and characteristics of Malaysian palm kernel cakes/ expellers. Palm Oil Developments, 34: 1-3.

Terry, D E; Agbaji, A S and Agbaji, E B (1992). Proximate composition of the seed Acasia nilotica Var adansonii (Bagaruwa) and extraction of its protein. Tropical Science, 32: 263-268.

Toride, Y (2000). Lysine and other amino acids for feed: Production and contribution to protein utilization in animal feeding. http://www.fao. org/3/y5019e/y5019e0a.htm, accessed on 2 January 2019.

Tzeng, Y M; Diosady, L L and Rubin, L J (1990). Production of canola protein materials by alkaline extraction, precipitation and membrane processing. J. Food Sci., 55: 1147-1156.

Wolf, W J (1970). Soybean proteins: Their functional, chemical and physical properties. J. Agric. Food Chem., 18: 969-976.

Xu, L and Diosady, L L (2003). Removal of phenolic compounds in the production of high-quality protein isolates. Food Research International, 35: 23-30. 
Zayas, J F (1997). Solubility of proteins. In Functionality of Proteins in Food. Springer, Berlin, Heidelberg.
Zhang, B; Cui, Y; Yin, G; Li, X and Zhou, X (2009). Alkaline extraction method of cottonseed protein isolate. Modern Appl. Sci., 3(3): 77-82. 